\title{
Overuse Injuries in Youth Sports: Legal and Social Responsibility
}

\author{
Phoebe Friesen, Bethany Saul, Lisa Kearns, \\ Kathleen Bachynski, and Arthur Caplan*
}

\begin{abstract}
Youth sports-related injuries represent a major public health challenge, and overuse injuries, which result from repetitive microtrauma and insufficient rest, are a particular and growing concern. Overuse injuries are increasingly prevalent within youth sports, can lead to lifelong disabilities, and are almost entirely preventable. We explore the question of whether parents, who have been shown to significantly influence their children's sports experiences and behaviors, can be held responsible for overuse injuries. We also discuss the role of other actors, including medical practitioners and coaches, and the duties that they may have to prevent such injuries to child athletes. We argue that, in many cases, contributions to overuse injuries are the result of non-culpable ignorance, and that a better way to help prevent overuse injuries may be to enact policies that educate parents, as well as schools, coaches, and organizations, about overuse injuries.
\end{abstract}

\section{Overuse Injuries in Youth}

Youth sports-related injuries represent a major public health challenge. Young people ages 5 to 24 years account for nearly two-thirds of sports- and recreationrelated injuries in the US (Sheu, Chen, \& Hedegaard, 2016). Sports injuries in children can damage growth mechanisms and have the potential to result in longterm harm (Shanmugam \& Maffulli, 2008).

Of the many types of injuries associated with youth sports, overuse injuries especially are a growing concern. The term "overuse" to describe sports injuries has been applied inconsistently in the medical literature, referring sometimes to a mechanism of injury and sometimes to a category of injury diagnosis (Roos \& Marshall, 2014). Epidemiologists have recommended using "overuse" exclusively in regard to the mechanism of injury. As such, overuse injuries can be defined as

\footnotetext{
* Phoebe Friesen, PhD, is a postdoctoral fellow in the Ethox Center at the University of Oxford; email: phoebe.friesen@ndph.ox.ac.uk. Bethany Saul is a JD candidate at New York University (NYU) Law School. Lisa Kearns, MS, MA, is a senior research associate in the Division of Medical Ethics at NYU School of Medicine. Kathleen Bachynski, PhD, is a Rudin postdoctoral fellow in the Division of Medical Ethics and Humanities at NYU. Arthur Caplan, PhD, is the Drs. William F. and Virginia Connolly Mitty Professor and Director of the Division of Medical Ethics at NYU School of Medicine.
} 
injuries that result from a mechanism of repetitive and cumulative microtrauma, without a specific onset incident (Roos \& Marshall, 2014). Importantly, overuse injuries are the result of repetitive stress on the musculoskeletal system that results when inadequate time for rest or recovery is taken (Biber \& Gregory, 2010; DiFiori, 2002). Examples of common pediatric and adolescent overuse injuries include rotator cuff tendinitis, apophysitis (inflammation of a bone growth plate), chronic anterior knee pain, and stress fractures (Soprano \& Fuchs, 2007).

Rapid changes in physical growth make children particularly vulnerable to overuse injuries, and these types of injuries are increasing among youth populations (Arnold, Thigpen, Beattie, Kissenberth, \& Shanley, 2017). A recent study examining visits to a sports clinic for youth ages 5 to 17 found that $53 \%$ of visits involved overuse injuries (Stracciolini et al., 2014). Rates of overuse injury vary by sport. An analysis of injuries among American high school athletes found that such injuries ranged from "a low of $1.4 \%$ of all boys' ice hockey injuries to a high of $55.7 \%$ of all boys' swimming and diving injuries" (Schroeder et al., 2015, p. 600). Overuse injuries in youth can lead to lifelong disabilities (McEwin \& Dickinson, 1996), and the extent of their harm may not be fully understood because they occur while children are still developing (Lowrey, Morain, \& Baugh, 2017).

Overuse injuries are particularly associated with sports specialization, defined as intense, yearlong participation in one sport to the exclusion of others (Jayanthi, Pinkham, Dugas, Patrick, \& LaBella, 2013; McGuine et al., 2017). Increasing evidence suggests that early specialization may be both "unnecessary" and "detrimental" (DiFiori et al., 2017). With the possible exception of women's rhythmic gymnastics, in which athletes reach their peak before full maturation, there is no evidence that one must specialize early in order to attain elite status in most sports (Güllich \& Emrich, 2014; Jayanthi et al., 2013; Vaeyens, Güllich, Warr, \& Philippaerts, 2009). A survey of Danish elite and near-elite athletes found that the elite athletes spent less time practicing their main sport before the age of 15 than the near-elite group (Moesch, Elbe, Hauge, \& Wikman, 2011). Additionally, early specialization has been linked to increases in injuries, psychological stress, and dropout from sports (Jayanthi et al., 2013). In an investigation of injury in high school athletes, the most significant risk factor for injury was found to be the athlete's amount of engagement in training (Rose, Emery, \& Meeuwisse, 2008). Early diversification in sports, in contrast, in which youth explore several sports and then may later choose to specialize in the one that they enjoy the most, has been found to be more likely to lead to success (Jayanthi et al., 2013).

Since overuse injuries are the result of repetitive stress without adequate rest time, they are considered to be preventable (Valovich McLeod et al., 2011). Speaking of the large and growing number of overuse injuries seen in youth sports today, experts emphasize that "we have to teach them that adequate rest and recovery is an integral part of training" (Biber \& Gregory, 2010, p. 292). But whom do we need to teach? In the following section, we consider the question of responsibility for overuse injuries in children, exploring the responsibility of various actors-parents, physicians and trainers, and coaches. In discussing the behaviors of these actors, we conclude that many of their contributions to overuse injuries in children in fact result from misinformation and a lack of understanding of the causes and impact of such injuries. We will conclude with 
some suggestions to address this ignorance that will better serve the fundamental goal of preventing overuse injuries in youth sports.

\section{Who Might Be Held Responsible for Overuse Injuries in Children?}

Legal liability for a participant's sports-related injury is generally predicated on a theory of negligence (McCaskey \& Biedzynski, 1996). Liability for negligent conduct requires establishing four elements: (1) a duty requiring a person to conform to a standard of conduct; (2) a breach of that duty; (3) a causal connection between the breach of duty and the resulting injury; and (4) resulting injury or damages (Hurst \& Knight, 2003, p. 32; McCaskey \& Biedzynski, 1996, pp. 1315). The most critical inquiry in determining who should be held responsible for overuse injuries in children is whether that actor has undertaken a duty of care and has breached that duty.

\section{A. Parents}

Although little research exists on the role of parents in contributing to overuse injuries, ample evidence establishes that parents are an important influence on their children's sports behavior. Parents can positively contribute to their children's sports experiences, and a majority do, as reported in a sample of junior tennis coaches (Gould, Lauer, Rolo, Jannes, \& Pennisi, 2006). Similarly, evidence suggests that parents are aware of the influence of their behavior on children and what constitutes virtuous spectator behavior (Wiersma \& Fifer, 2008).

However, parental pressure related to youth involvement in sports can also be damaging. Parents have been called "the primary agents for socializing young children under the age of 15 into sports," and many of them become heavily invested in the success of their child (Jacobs, 2007, p. ii). On youth soccer teams, it was found that when players have parents whom they perceive as critical and as having high achievement standards, they tend to worry more about their performance, believe less in their capabilities, and perceive the team atmosphere as less friendly (Ommundsen, Roberts, Lemyre, \& Miller, 2006). Given the fact that youth report "fun" as the primary reason they participate in sports, and a lack of fun as the primary reason they would drop out (Visek et al., 2015), parental pressure is unfortunate. DiFiori explains this link between pressure and youth disengagement from sports:

Coaches and parents may lack knowledge about normal development and signs of readiness for certain tasks, physically and psychosocially. This can result in unrealistic expectations that cause children and adolescents to feel as if they are not making progress in their sport. Consequently, children may lose self-esteem and withdraw from the sport. (DiFiori et al., 2014, p. 2)

Evidence suggests that a disconnect between children's and parents' experience of youth sports is common. Youth hockey players have been found to consistently rate the level of pressure from their parents higher than their parents do (Kanters, Bocarro, \& Casper, 2008). In this study, the most significant 
predictor of the participants' negative feelings about hockey was the level of pressure perceived from their fathers. Findings from surveys of youth involved in basketball and their parents revealed that parents tend to see themselves and their involvement in their child's sport more positively than their children do (Hendley, 2005). This has led one commentator to conclude, "what parents want and what parents hope to gain from their children's participation in organized youth sports is often at a polar extreme to what their kids want" (Cox, 2011, p. 1).

Although not directly related to overuse injuries, further evidence that parents can significantly influence the experience of their children within sports is found in research on sportsmanship behaviors. An association between perceived negative behavior from spectators and youth reports of their own poor sportsmanship has been found (Shields, LaVoi, Bredemeier, \& Power, 2007). Negative sportsmanship in spectators appears to be a better predictor of negative youth behavior than negative sportsmanship in coaches (Arthur-Banning, Wells, Baker, \& Hegreness, 2009). However, joint pressure from both parents and coaches has been found to correlate with "maladaptive achievement striving" in youth (Ommundsen et al., 2006, p. 522). As Huston has argued, "parents who display poor sportsmanship and engage in activities that create a collective norm that does not promote sportsmanship and essential core values such as discipline, respect, responsibility, fairness, trustworthiness, teamwork, good citizenship, positive competition, and the spirit of excellence, have a profound effect on the sportsmanship of youth sports participants" (Huston, 2017, p. 36).

An increasing emphasis on competitive success in youth sports has been offered as an explanation for the pressure exerted by parents on their children (DiFiori, 2002). Other reasons include the commercialization of youth sports leagues (Frankl, 2004) and the motivation of "achievement by proxy" (Tofler, Knapp, \& Drell, 1999). It is also suggested that parental misperception of the likelihood of success - imagining that elite, college, or professional play is just around the corner, when in reality the chances of entry there are extremely low (Logan, 2015) - contributes to this pressure. As Cox reports, even if children excel on their youth sports team, "very few age-group sports stars ever end up being successful in professional or Olympic sports" (Cox, 2011, p. 72). Additionally, parents of youth playing sports often share in the emotions of their child, which can contribute to their investment in the game and sometimes to inappropriate pressure and responses to their child's success (Holt, Tamminen, Black, Sehn, \& Wall, 2008). Interviews with parents of youth in sports revealed that several reported "adopting a 'whatever it takes' attitude toward the achievement of their children's sport goals" (Dorsch, Smith, \& McDonough, 2009, p. 459). All of these factors may contribute to the increase of reports of parents at youth sporting events engaging in inappropriate behavior, and the development of interventions like "Codes of Conduct," "Silence on the Sidelines Days," "Parent Conduct Enforcers," severe sanctions, and fines to prevent such behavior (Frankl, 2004; Huston, 2017).

Against this backdrop of parental influence, we assess the potential for parental legal liability for the overuse injuries of their minor children. We first ask whether the parent owes a duty of care and whether the parent has breached that duty. It is nearly universally accepted that parents have both special rights 
and duties when it comes to their children (the term "parent" meaning primary caregivers). In the US, the rights of parents to control their children is recognized in law as "perhaps the oldest of the fundamental liberty interests" (Troxel $v$. Granville, 2000; Meyer v. Nebraska, 1923; Pierce v. Society of the Sisters, 1925; Prince v. Massachusetts, 1944). Given that minors are still developing the capacity to make autonomous decisions for themselves, and since the law imposes high duties on parents to rear and discipline their children, parents are granted the right to act with wide discretion in relation to their children, making choices for them rather than allowing children to choose (Emery v. Emery, 1955). The sum of parental rights includes the right to direct their children's activities and make decisions regarding their care and control, education, and health (Burge $v$. San Francisco, 1953).

Rights of parents are not absolute but are predicated on the fulfillment of duties, all of which fall under the general duty to act in the best interests of the child (Parham v. J.R., 1979). Put another way, "parents are primarily responsible in assisting children to develop into adults who have a good life and live a good life" (Le Sage \& De Ruyter, 2008, p. 790). Legal consideration of the "best interests" of the child typically emerges in the context of child custody or parental visitation, although it has also arisen in the context of medical care. The U.S. Supreme Court has recognized the parental duty to "recognize symptoms of illness and to seek and follow medical advice" (Parham v. J.R., 1979). When parents fail in that duty and jeopardize the "physical and mental health" of minor children, the state has the power to intervene and supersede parental discretion (Parham v. J.R., 1979). Analogously, one might argue that parents breach this "best interests" duty when they direct their children to specialize in a single sport with disregard to the risk of overuse injuries. However, the law presumes that fit parents act in the best interests of their child (Troxel v. Granville, 2000). Absent evidence of unfitness, parental decisions about sports participation will ordinarily be presumed consistent with the child's best interests.

A different legal rubric may better regulate parental treatment of children in sports programs. Some scholars suggest that parental conduct in youth sports can rise to the level of child abuse (Abrams, 2001), though there is currently little legal precedent suggesting a court would find parents liable for such a charge. Extreme cases exist, such as, for example, very young children training for the Olympics. Some parents have also arranged for the performance of surgeriesprophylactic ulnar collateral ligament reconstruction and "Tommy John" tendon reconstruction surgery - to ensure enhanced athletic performance (Erickson et al., 2015). In the cases of overuse injuries, physician Paul Lin has suggested that if a father allowed his child to continue playing football after sustaining multiple injuries, this should constitute child abuse (Cook, 2017). Such cases may in fact fall within existing state statutory schemes that protect children from parental abuse.

The relative lack of legal attention to potentially abusive relationships between a parent and child in this setting suggests an opening for state governments to better regulate parental conduct when involving their children in competitive sports: 
We have laws in this country about child labor. We restrict the age for drinking and driving. We legislate against secondhand smoke. We vigilantly guard for signs of child exploitation, child neglect and child abuse. Yet every day, all over the United States, parents sign their children into youth sports programs that have few if any limits on how many games their children will be forced to play, how hard and at what costs they will be pushed to win, and how young they will be held to adult standards, adult goals, adult-strength stress. (Bigelow, Moroney, \& Hall, 2001, p. 29) cited in (Cox, 2011)

Kamm has made a similar comparison between competitive youth sports and child labor. "We enacted child labor laws eighty years ago to protect children from all this work. And now basically we're making play into work" (McMahon, 2007, p. 66); cited in (Cox, 2011). While the parens patriae powers of governments has historically resulted in regulation of child employment, this governmental power may be broader. After all, it is within the power of the state to regulate activities of children in the interest of ensuring the "healthy, well-rounded growth of young people" (Prince v. Massachusetts, 1944).

In the absence of state regulations and a lack of political will to enforce child abuse charges related to overuse injuries, there is a third, albeit limited option to place responsibility on parents for overuse injuries in their children. There is potential for civil remedies for children against their parents. Generally, the doctrine of parental immunity shields parents from liability when children seek to recover damages for injuries caused by their parents' negligent supervision (Maldonado v. Newport Gardens, Inc., 2012). The doctrine reflects judicial hesitancy to impose its opinion of "proper parenting" (Zellmer v. Zellmer, 2008). As such, courts are unlikely to allow children to pursue negligence claims against parents in cases where a parent is simply choosing an activity for the child to participate in (Zellmer v. Zellmer, 2008). Other states simply say that a parent's failure to supervise a child is not recognized as a tort actionable by the child (Abdel-Gawad v. Abdel-Gawad, 2009).

However, when there is a specific danger that an injury is imminent and foreseeable (not likely in most cases of overuse injuries), or when a parent is aware of the danger that the child faces but still exposes the child to it, there may be an exception to parental immunity and the parent's negligence may be actionable (Martin v. Yunker, 1993; Zellmer v. Zellmer, 2008). For instance, when a parent's failure to inform a scuba diving school of his child's severe learning disability resulted in the child's death, the court allowed the school to pursue a contribution claim against the parent. Even though the parent has broad discretion to involve his child in recreational activities, and doing so is generally immune from liability, the parent's concealment of material information was "palpably unreasonable." In such a case, the parent may forfeit his immunity and a jury could find that the parent's conduct was grossly negligent (Martin v. Yunker, 1993). The Martin court did, however, underline that in the absence of such gross negligence, "attendance at a sports or recreational activity" is generally protected parental conduct (Martin v. Yunker, 1993).

Excluding egregious examples of gross negligence and child abuse, parental ignorance largely explains children's overuse injuries. Many parents do not have 
a clear understanding of what they should expect from their children within normal development (DiFiori, 2002). Parents also appear to be unaware of the pressures they can exert on their children and the harms they can cause in terms of enjoyment, engagement, and behavior in sports (Hendley, 2005; Kanters et al., 2008). Additionally, many parents also appear to falsely believe that early specialization is crucial to success, despite the lack of evidence for this thesis (DiFiori et al., 2017). Notably, coaches also tend to falsely believe in the importance of early specialization for success (DiFiori et al., 2017). Some parents expect that specialization is likely to lead to significant payouts in the long run, while in reality those who are successful in youth sports very rarely continue to become elite adult athletes (Cox, 2011; Logan, 2015). Finally, parents are unlikely to have a clear understanding of how repeated microtraumas can contribute to long-term injuries in their children. Thus, even in cases in which parents play a significant role in contributing to decisions that lead to overuse injuries in their children, these decisions may be the result of ignorance.

Many parents, lacking an understanding of the actual risks and benefits present in their child's sport, are acting in what they believe is the best interest of their child. If so, cases of overuse injuries may be more akin to cases of vaccine hesitancy, in which parents refuse to vaccinate their children as a result of believing that the risks outweigh the benefits. This appears to be the case in many youth sports, since many parents appear to be misinformed with regard to the risk-benefit ratios involved in youth sports. They may be focusing on the many real benefits of engaging in sports, related to physical health, wellbeing, identity development, and emotional development (Hansen, Larson, \& Dworkin, 2003), as well as self-esteem and peer socialization (DiFiori, 2002), and be unaware of the risks that come with early specialization, excessive training, and parental pressure. However, there is a noteworthy difference between overuse injuries and vaccine hesitancy. Failing to prevent an overuse injury puts only one child at risk, whereas a failure to vaccinate can put many more children and individuals, especially those who are unable to be vaccinated themselves because they are immunocompromised, at risk as well.

Ultimately, the legal literature and precedent reveals limited potential for finding parents culpable for their children's overuse sports injuries. Reluctance to recognize a parental duty to protect children from overuse injuries in sports reflects, in part, the fact that parents are not necessarily aware of the causes and manifestations of such injuries. Over time, there is potential for this to change. As knowledge of new parenting practices becomes commonplace, these practices are often incorporated into routine parental monitoring norms (G. Bernstein \& Triger, 2010). These monitoring norms may transform into legal duties over time, which is illustrated through parental liability for lead-caused injuries, legislative measures preventing alcohol consumption by pregnant women, and childhood obesity as a factor in neglect and abuse proceedings and custody determinations (G. Bernstein \& Triger, 2010, p. 1252).

Given the significant influence that parents have on their children's experiences in sports, in terms of involvement, enjoyment, and behaviors, it is likely that parents also heavily influence decisions that may contribute to overuse injuries. These include whether to specialize in one sport early on, how often children engage in training, and whether and when to return to play after sustaining an 
injury. However, parental ignorance about overuse injuries and a relative lack of legal duty to protect from such injuries, excluding egregious cases of abuse, suggests looking for different solutions to prevent such injuries. We now turn to the conduct and potential duties of other actors, primarily medical practitioners and coaches, who also contribute to overuse injuries of children.

\section{B. Physicians}

Many actors in addition to parents contribute to youth sports decisions in ways that may lead to overuse injuries. In particular, school and team physicians play a substantial role in determining whether a child can continue playing or training in a particular sport. Many schools select a physician to provide pre-participation physical examinations and emergency care to athletes participating in school athletics (Mitten, 2002).

To assess the potential for legal liability for overuse injuries of minors, we first ask whether a team physician owes a duty of care and whether the physician has breached that duty. A team physician has a well-established duty to adhere to customary sports medicine practice in diagnosing or treating an athlete's injuries (Mitten, 2002). How far this duty extends is unclear. While the expanding role of physicians may increase their legal exposure, few reported appellate cases discuss the appropriate standard of care for sports medical professionals facing a claim of overuse injuries in competitive athletes, let alone child athletes. At least one court has determined that a school physician's duty is limited to properly administering a state education department screening test for athletic participation (Sitomer v. Half Hollow Hills Central School District, 1987). In Sitomer, the student claimed that the school physician was negligent in refusing to medically clear him for play based on a screening test that found the student not sufficiently physically mature. The court held that as long as the exam was properly conducted, the doctor did not breach a duty. Yet, as physicians take on greater responsibility for return to play (RTP) decisions in minor athletes, they may find themselves taking on a correspondingly greater legal duty (Serrell $v$. Connetquot Central High School District of Islip, 2001).

In the case of RTP decisions for young athletes, some argue that it is ultimately the duty of a sports medicine physician to make the appropriate assessment of recovery time, assess the level of acceptable risk, and provide the final return to play clearance (Liem, Olafsen, Harrast, \& Herring, 2016). For instance, in Serrell v. Connetquot Central High School District of Islip, the Court "ultimately placed the responsibility for determinations concerning injuries and the return to play after an injury on the medical personnel examining and/or treating the injured student" when the school and district had promulgated rules concerning head injuries (Serrell, 2001). The Code of Ethics of the International Federation of Sports Medicine (FIMS) also maintains, "it is the responsibility of the sports medicine physician to determine whether the injured athletes should continue training or participate in competition" (Code of Ethics).

Even if the physician may technically have the "final say," the patient-physician relationship in youth sports is rarely dyadic in nature, and is more often composed of a triad among the physician, the patient (whose decision-making authority is shared with his/her parents), and the team coach (Huston, 2017). 
Importantly, because physicians may not be present during play or practice, the coach often assumes the role of "immediate health care provider" and so is often responsible for decisions regarding seeking care or returning to play during both training and game play (Huston, 2017). However, it is reasonable to conclude that any person involved in RTP decisions exposes him/herself to liability for negligent RTP clearances, including team physicians (Wilson, 2010).

\section{Coaches}

Some evidence suggests that coaches may be a more important contributor than parents to risky decisions that contribute to overuse injuries (Hurst \& Knight, 2003). A survey of elite youth athletes found that while parents were the most significant influence in terms of which sport a child chose to play, coaches were the most significant influence in relation to the decision to engage in intense training (Baxter-Jones \& Maffulli, 2003). Similarly, Hill and Simons found coaches to be the more significant influence over youth decisions to specialize in a single sport (Hill \& Simons, 1989). Youth players often learn a particular sports ethic from their coaches as well, one that often normalizes the experience of pain and the teaches youth to value "mental toughness" (Cavallerio, Wadey, \& Wagstaff, 2016). Observational research of girls' softball teams found that coaches would frequently ignore players' complaints about pain, tell them to "shake it off," and even make jokes about those with physical complaints (Malcom, 2006). Extrapolating on the disconnect between parents who may introduce a child to a sport and coaches who may encourage vigorous training, Jayanthi et al. suggest, "The parent may acknowledge and encourage increased participation, not want to interfere with the child-coach relationship, and/or assume that this path is necessary for continued success" (Jayanthi et al., 2013, pp. 251-252).

Legal decisions resulting from youth sports injuries also point more frequently toward liability of coaches and schools (McEwin \& Dickinson, 1996). As Dobberstein explains, courts are increasingly adopting the position that "high schools and their employees must exercise reasonable care to protect student-athletes from injury" (Dobberstein, 2007, p. 2). An increase in these kinds of cases is affecting expectations of both coaches and institutions in relation to injury.

As with the duties owed by physicians and parents to child sports participants, standards of care differ by state. However, the standard of care a coach owes to a child athlete is widely contested (Hurst \& Knight, 2003). Coaches generally do not have a duty to protect the athlete from the risks inherent in sports. However, most courts impose a duty on a coach not to increase the risk of harm beyond what is inherent in the sport (Knight v. Jewett, 1992). Case law and legal commentary have further identified a coach's duty to include, variously: (1) supervision; (2) training and instruction; (3) ensuring the proper use of safe equipment; (4) providing competent and responsible personnel; (5) warning of latent dangers; (6) providing prompt and proper medical care; (7) preventing injured athletes from competing; and (8) matching athletes of similar competitive levels (McCaskey \& Biedzynski, 1996, pp. 15-16).

While the majority of claims against coaches and school districts related to athlete injuries concern inadequate supervision (McCaskey \& Biedzynski, 1996), in a number of cases students and former student athletes allege negligence against 
coaches and school districts for injuries related to their ongoing involvement in school sports. In Besler, a former high school student and star basketball player filed tort claims against her coach and the school, among others, alleging emotional distress from an eating disorder and amenorrhea allegedly resulting from the continual actions of her coach who told her to lose weight and was verbally abusive (Besler v. Board of Educ. of West Windsor-Plainsboro Regional School Dist., 2008). The coach's insistence on weight loss was to improve the child's and the team's performance. A jury found the coach liable for negligence, reckless infliction of emotional distress, and extreme and outrageous conduct, although it rejected the claim for intentional infliction of emotional distress. Furthermore, the school was found liable for breach of its parens patriae role. While this case does not involve an overuse injury, the finding of a coach and school liable for negligent conduct demonstrates the willingness of a jury to address potential abuse in negative coaching practices. Applying similar reasoning in Vargo $v$. Svitcahn, the Michigan Court of Appeals allowed the jury to decide whether the athletic director of a high school program was negligent when a coach's forceful instruction resulted in a player's paralysis (Vargo v. Svitcahn, 1980).

Much like parental duties to a child athlete, coaches and schools likewise have a duty to protect child athletes from injuries that are immediate and foreseeable. For instance, a college basketball coach was found liable for a minor athlete's injuries when the coach pressured the youth to return to play despite visible evidence of continued physical impairment from a prior injury (Lamorie v. Warner Pacific College, 1993). While the case law acknowledges that youth athletes assume the risk of the inherent dangers of the sports they play, they do not assume the risk of a coach's negligent supervision of the team. Thus, a school or coach may be held liable for allowing a student to play when they knew the student was previously injured (Zalkin v. American Learning Systems, Inc., 1994). Similarly, a coach was held liable for breaking a promise to an undersized football player not to play him against much bigger opponents. Despite the known risks of tackle football, the court allowed the football player to pursue a claim of negligent supervision of the sport (City of Miami v. Cisneros, 1995). And while liability for negligent supervision can be based on a failure to notice symptoms of heatstroke or heart attack, a symptomless player who suddenly collapses while practicing in hot weather has no claim when he could have opted out of practice, or stopped at any time to rest or get water (Tarlea v. Crabtree, 2004; Draughon v. Harnett County Board of Education, 2004).

Many states immunize public schools and their employees with parental immunity in matters relating to discipline and supervision of students, which may exacerbate the coach's role in contributing to a minor's overuse injuries (Prest by Prest v. Sparta Cmty. Unit Sch. Dist. No. 140, 1987). In those states, a coach will not be held liable if the overuse injury arguably resulted from "matters relating to discipline in and conduct of the schools and the school children" and no willful or wanton misconduct occurred (Kobylanski v. Chicago Bd. of Ed., 1976; Tanari v. Sch. Directors of Dist. No. 502, Bureau County, 1977). In addition, many schools and coaches are protected from liability by virtue of pre-injury waivers of liability signed by the parents on behalf of minor participants. Such waivers are often at the center of disputes in cases of youth sports, including injuries from soccer 
(Zivich v. Mentor Soccer Club, 1998), hockey (Fischer v. Rivest, 2002), dodgeball (Blackwell v. Sky High Sports Nashville Operations, 2016), cheerleading (Sharon v. City of Newton, 2002), and gymnastics (Quirk v. Walker's Gymnastics \& Dance, 2003). However, not all states enforce such pre-injury waivers of liability (Arters \& Rose, 2016).

Despite waivers and parental immunity defenses, coaches remain primarily responsible for proper supervision of minor sports participants. Negligent supervision will ordinarily result in liability for youth sports injuries, assuming causation can be established (McCaskey \& Biedzynski, 1996). However, with overuse injuries, the causal chain from negligent supervision to the ultimate injury is more tenuous, with multiple factors and actors involved, so that coaches may get a pass.

Of course, young athletes themselves are also of central importance in making decisions that may lead to overuse injuries. Although some very young athletes have arguably little autonomy in terms of their engagement in sports (e.g., a 5-year-old playing soccer or distance running [Wade, 2014]), adolescent athletes who are near adulthood are likely to have a fairly good understanding of the contours of the decisions they are required to make related to their sport. However, even if it is their decision, the choice they make may be the result of many external expectations surrounding them. As Liem et al. explain,

Outside stakeholders may exert influence on the doctor patient dyad, introducing competing interests other than the athlete's health and safety. As the level of competition increases, the number of external stakeholders often increases. Youth and high school athletes may feel pressure primarily from parents, coaches, and teammates to RTP [return to play] before they are physically and psychologically ready. (Liem et al., 2016, p. S140)

As with parents, both youth and coaches have been found to lack awareness of the causes and prevalence of overuse injuries. A survey of youth baseball players (ages 9-16) found that 62\% disagreed with the statement, "The more you throw, the more likely you are to get an injury," and 57\% said they would not seek medical assistance if their arm was tired or sore during a game (Bohne, George, \& Jr, 2015). Focus groups of several stakeholders involved in youth track and field revealed that one of the primary reasons for injury was thought to be insufficient knowledge of both youth development and health maintenance, particularly among coaches. One participant remarked that "Many youth coaches - mostly the young ones - have no understanding of the importance of low-intensity conditioning training" (Jacobsson, Bergin, Timpka, Nyce, \& Dahlström, 2017, p. 351). This suggests that ignorance with regards to overuse injuries is a widespread issue, and that preventing overuse injuries will require looking at the broad range of individuals and institutions that shape youth sports. 


\section{Shifting to Two Alternative Questions}

If it is indeed the case that most behavior contributing to overuse injuries is being driven by misinformation or a lack of understanding, a more interesting and important question might be: where is that misinformation coming from? We offer some preliminary suggestions in hopes of initiating a larger discussion, and gesture toward some initiatives that may be particularly effective in addressing such ignorance.

\section{A. What Causes This Ignorance?}

As Logan puts it, the "lure of potential elite, college, and professional sport involvement is strong, but deceptive" (Logan, 2015, p. 517). To understand why so many parents and coaches falsely believe that early specialization will increase the likelihood that a child will be the one to make it to an elite level-that "more is better" when it comes to youth sports (Logan, 2015, p. 517) - it is important to look to larger, structural influences that are shaping perceptions related to youth sports.

One factor that may be contributing to parents' willingness to encourage their children to specialize early and train to excess is the widespread availability of programs that offer this form of sports engagement. If the local YMCA, Pop Warner, public school, or travel team are all offering intense, highly competitive forms of training that allow for early specialization, it is understandable that parents would assume that it is a safe thing for their child to do. One comparison might be the availability of over-the-counter drugs in pharmacies. Consumers generally assume that such drugs have met U.S. Food \& Drug Administration (FDA) approval and are safe for purchase; analogously, parents who see a particular youth training regimen advertised online or at a youth league down the street might reasonably believe that such a regimen is low risk. Sports organizations and administrators who make year-round, intense, highly competitive sports available to children in the first place may be shaping parents' perception of the risks.

What has been called a "culture of risk" within sports is also likely to contribute to the lack of awareness surrounding overuse injuries (Nixon, 1993). In general, Nixon explains, this culture ensures that "athletes are exposed to mediated - and more direct-messages that tell them they must play as long as possible with pain and injuries and must try to come back as soon as possible after serious injuries" (Nixon, 1993, p. 188). Such a culture is not limited to elite settings, but appears to permeate sports at all levels (Liston, Reacher, Smith, \& Waddington, 2006). In youth sports leagues, the existence of this culture of risk, primarily in the form of behaviors and attitudes contributing to pain normalization, has been documented, and is likely to undermine efforts to prevent overuse injuries (Cavallerio et al., 2016; Malcom, 2006).

Additionally, a growing acceptance of the central place of competition in youth sports is likely to lead to an increase in parental pressures to succeed, as well as to the normalization of risky behaviors in youth sports. An emphasis on competitive success has become widespread, resulting in an increased pressure to begin high-intensity training at young ages (DiFiori, 2002). Financial 
competition has also infiltrated many leagues, leading to additional pressure to succeed, and creating conflicts of interest for many. As Frankl has said, "Leagues that were started and run by well-intentioned adults turn over time into commercialized and highly competitive enterprises" (Frankl, 2004).

\section{B. What Can Be Done?}

Examining the large-scale forces that influence parents' perceptions of what is acceptable when it comes to youth sports leads to the related question of how we might best prevent overuse injuries.

Certainly, the education of parents, coaches, physicians, and players about the benefits of early diversification and the harms of early specialization, including stress, injury, and burnout, is crucial. Training programs for coaches regarding the safety of players have proven effective in this regard (Kerr et al., 2016). Similarly, misperceptions related to the likelihood of youth becoming elite athletes ought to be corrected, and the links between parental pressure and child disengagement should be publicized. Avenues for such education can include the media, public service announcements, and messaging from professional youth sports organizations and athletic associations.

Legislation can also help reshape perceptions of what is permissible in terms of risks. A law recently passed in California restricts tackling practice during the high school football season to two 90-minute practices a week (S. Bernstein, 2014). This intervention takes place right at the source of overuse injuries. Since it is known that the more risky training one engages in, the more likely one is to sustain an injury, restricting practice is likely to directly reduce rates of injury in young football players in California (Rose et al., 2008). Although there is no direct evidence, it is likely that now, many more parents and coaches in California are aware of the risks of tackle football than before such legislation was passed, especially given the significant decline in high school football participation in the state (Sondheimer, 2017). Similarly, programs shifting from tackle football to flag football for young children also send a message about risk, and can help promote safe youth sports practices (Dwyer, 2015). It is worth noting that "return to play" laws have been passed in some form in every state. However, many are concerned that these laws do not focus enough on prevention as the aforementioned California legislation, as they only apply once an acute injury has been sustained (Lowrey et al., 2017). For this reason, RTP laws in many states are unlikely to be very effective at preventing overuse injuries that are a result of repetitive microtraumas.

Here, again, the issue of overuse injuries resembles that of vaccine hesitancy, in which it is becoming clear that blaming and prosecuting individuals is unlikely to resolve the underlying problem. In the case of vaccine hesitancy, public health advocates and medical professionals have focused attention on legislating state statutes requiring vaccination for public school entry (Hodge Jr \& Gostin, 2001), in combination with a growing educational movement (Larson, Jarrett, Eckersberger, Smith, \& Paterson, 2014). All states, as a condition of school entry, require proof of vaccination against a number of diseases (Hodge Jr \& Gostin, 2001). Meanwhile, advocates seek to identify, educate, and address the complex sources of inaccurate beliefs about the dangers of vaccines (Larson et al., 2014). 
This two-pronged approach to address vaccine hesitancy provides a useful model for reducing incidences of overuse injuries. Perhaps the best chance of ultimately reducing incidences of overuse injuries in children lays in tailored state statutes that seek to prevent repetitive microtraumas, in combination with an educational campaign that seeks to instruct the myriad actors in childhood athletics about the causes and harms of such injuries.

\section{Conclusion}

Overuse injuries are becoming epidemic among young American athletes. They extract a huge toll in terms of disappointment, short- and long-term disability, and health care costs. Current efforts to manage overuse injuries are being overwhelmed by the commercialization of youth sports, which encourages yearround participation and specialization. Parents play a key role in controlling the sports behavior of their children, so it may make sense to seek to enact public policies that hold them, as well as coaches and organizations promoting behavior known to place children at risk, responsible. Exploring whether to take legal action against parents, coaches, physicians, or organizations for overuse injuries under the framework of child abuse is one potential strategy for protecting vulnerable children. On the other hand, general knowledge about the dangers and risks that lead to overuse injuries are not well-understood by parents and sometimes coaches. And parents may believe that pushing their children to play a single sport year-round may be helping them succeed rather than exposing them to harm. Before moving toward more punitive measures, more emphasis must be placed on medical groups, parent associations, coaching organizations, sports equipment manufacturers, and school officials to educate parents about the extent, causes, and consequences of overuse injuries. In addition, league and state policies that restrict how often school sports programs allow children to engage in repetitive, risky sports techniques may reduce overuse injuries. They may also contribute to resetting adult expectations and shifting youth sports culture toward safer training practices.

\section{Cases}

Abdel-Gawad v. Abdel-Gawad, 882 N.Y.S.2d 425. New York State, Appellate Division, Second Department. 2009.

Besler v. Board of Educ. of West Windsor-Plainsboro Regional School Dist., 2008 WL 3890499. Superior Court of New Jersey, Appellate Division. 2008.

Blackwell v. Sky High Sports Nashville Operations, 523 S.W.3d 624. Court of Appeals of Tennessee. 2016.

Burge v. San Francisco, 41 Cal.2d 608. Supreme Court of California. 1953.

City of Miami v. Cisneros, 662 So. 2d 1272. District Court of Appeals of Florida, Third District. 1995.

Draughon v. Harnett County Bd. of Educ., 158 N.C. App. 705. Court of Appeals of North Carolina. 2003.

Emery v. Emery, 45 Cal.2d 42. Supreme Court of California. 1955.

Fischer v. Rivest, 2002 WestLaw 31126288. Superior Court of Connecticut. 2002. 
James v. Laurel School District, 1993 WL 81277. Superior Court of Delaware, Sussex County. 1993. Knight v. Jewett, 3 Cal. 4th 296. Supreme Court of California. 1992.

Kobylanski v. Chicago Bd. of Ed., 63 Ill. 2d 165. Supreme Court of Illinois. 1976.

Lamorie v. Warner Pacific College, 119 Or. App. 309. Court of Appeals of Oregon. 1993.

Lennon v. Peterson, 624 So.2d 171. Supreme Court of Alabama. 1993.

Maldonado v. Newport Gardens, Inc., 937 N.Y.S.2d 260. Court of Appeals of New York State, Second Department. 2012.

Martin v. Yunker, 121 Or. App. 74. Court of Appeals of Oregon. 1993.

Meyer v. Nebraska, 262 U.S. 390. Supreme Court of the United States. 1923.

Parham v. J.R., 442 U.S. 584, 602. Supreme Court of the United States. 1979.

Pierce v. Society of the Sisters, 268 U.S. 510. Supreme Court of the United States. 1925.

Prest by Prest v. Sparta Cmty. Unit Sch. Dist. No. 140, 157 Ill. App. 3d 569. Appellate Court of Illinois, Fifth District. 1987.

Prince v. Massachusetts, 321 U.S. 158. Supreme Court of the United States. 1944.

Quirk v. Walker's Gymnastics \& Dance, 2003 WestLaw 21781387. Superior Court of Massachusetts. 2003.

Serrell v. Connetquot Central High School District of Islip. 721 N.Y.S.2d 107. New York Supreme Court, Appellate Division, Second Department. 2001.

Sharon v. City of Newton, 769 N.E.2d 738. Supreme Judicial Court of Massachusetts, Middlesex. 2002.

Sitomer v. Half Hollow Hills Central School District. 520 N.Y.S.2d 37. New York Supreme Court, Appellate Division, Second Department. 1987.

Tanari v. Sch. Directors of Dist. No. 502, Bureau Cty., 69 I11. 2d 630, 635-36. Supreme Court of Illinois. 1977.

Tarlea v. Crabtree, 263 Mich. App. 80. Court of Appeals of Michigan. 2004.

Terror Mining Co. v. Roter, 866 P2d 929. Supreme Court of Colorado. 1994.

Troxel v. Granville, 530 U.S. 57. Supreme Court of the United States. 2000.

Vargo v. Svitcahn. 301 N.W.2d 1. Michigan Court of Appeals. 1980.

Zalkin v. American Learning Systems, Inc., 639 So. 2d 1020. District Court of Appeals of Florida, Third District. 1994.

Zellmer v. Zellmer, 164 Wash.2d at 161. Supreme Court of Washington. 2008.

Zivich v. Mentor Soccer Club, 696 N.E.2d 201, 205-07. Supreme Court of Ohio. 1998.

\section{References}

Abrams, D. E. (2001). The challenge facing parents and coaches in youth sports: Assuring children fun and equal opportunity. Vill. Sports \& Ent. LJ, 8, 253.

Arnold, A., Thigpen, C. A., Beattie, P. F., Kissenberth, M. J., \& Shanley, E. (2017). Overuse Physeal Injuries in Youth Athletes. Sports Health, 9(2), 139-147. https://doi. org/10.1177/1941738117690847

Arters, J. D., \& Rose, B. M. (2016). Kindly Remove My Child from the Bubble Wrap-Analyzing Childress v. Madison County and Why Tennessee Courts Should Enforce Parental Pre-Injury Liability Waivers. Tenn. JL \& Pol'y, 11, 8. 
Arthur-Banning, S., Wells, M. S., Baker, B. L., \& Hegreness, R. (2009). Parents behaving badly? The relationship between the sportsmanship behaviors of adults and athletes in youth basketball games. Journal of Sport Behavior, 32(1), 3.

Baxter-Jones, A., \& Maffulli, N. (2003). Parental influence on sport participation in elite young athletes. Journal of sports medicine and physical fitness, 43(2), 250.

Bernstein, G., \& Triger, Z. (2010). Over-parenting. UC Davis L. Rev., 44, 1221.

Bernstein, S. (2014, July 21). California law limits school football practices to cut concussions. Reuters. Retrieved from http://www.reuters.com/article/us-usa-california-football-schools-idUSKBN0FQ29B20140721

Biber, R., \& Gregory, A. (2010). Overuse injuries in youth sports: is there such a thing as too much sports? Pediatric Annals, 39(5), 286-292.

Bigelow, B., Moroney, T., \& Hall, L. (2001). Just let the kids play: How to stop other adults from ruining your child's fun and success in youth sports.

Bohne, C., George, S. Z., \& Jr, G. Z. (2015). Knowledge of injury prevention and prevalence of risk factors for throwing injuries in a sample of youth baseball players. International Journal of Sports Physical Therapy, 10(4), 464-475.

Cavallerio, F., Wadey, R., \& Wagstaff, C. R. D. (2016). Understanding overuse injuries in rhythmic gymnastics: A 12-month ethnographic study. Psychology of Sport and Exercise, 25, 100109. https://doi.org/10.1016/j.psychsport.2016.05.002

Code of Ethics. Retrieved from http://www.fims.org/about/code-ethics/

Cook, B. L. (2017, August 14). Paul M. Lin, 91, distinguished neurosurgeon in Philly and beyond. The Inquirer. Retrieved from http://www.philly.com/philly/obituaries/paul-m-lin-91-distinguished-neurosurgeon-in-philly-and-beyond-20170814.html

Cox, J. D. (2011). The professionalization of youth sports in America.

DiFiori, J. P. (2002). Overuse injuries in young athletes: An overview. Athletic Therapy Today, $7(6), 25-29$.

DiFiori, J. P., Benjamin, H. J., Brenner, J. S., Gregory, A., Jayanthi, N., Landry, G. L., \& Luke, A. (2014). Overuse injuries and burnout in youth sports: A position statement from the American Medical Society for Sports Medicine. British Journal of Sports Medicine, 48(4), 287-288.

DiFiori, J. P., Brenner, J. S., Comstock, D., Côté, J., Güllich, A., Hainline, B., \& Malina, R. (2017). Debunking early single sport specialisation and reshaping the youth sport experience: An NBA perspective. British Journal of Sports Medicine, 5I(3), 142.

Dobberstein, M. J. (2007). "Give me the ball, coach": A scouting report on the liability of high schools and coaches for injuries to high school pitchers' arms. Sports Lawyers Journal, 14, 49-269.

Dorsch, T. E., Smith, A. L., \& McDonough, M. H. (2009). Parents' perceptions of child-to-parent socialization in organized youth sport. Journal of Sport and Exercise Psychology, 31(4), 444468.

Dwyer, D. (2015). Somerville changing youth football league from tackle to flag citing injury concerns. boston.com. Retrieved from https://www.boston.com/news/local-news/2015/12/31/ somerville-changing-youth-football-league-from-tackle-to-flag-citing-injury-concerns

Erickson, B. J., Nwachukwu, B. U., Rosas, S., Schairer, W. W., McCormick, F. M., Bach, B. R., . . Romeo, A. A. (2015). Trends in medial ulnar collateral ligament reconstruction in the United States. The American Journal of Sports Medicine, 43(7), 1770-1774. https://doi. org $/ 10.1177 / 0363546515580304$

Frankl, D. (2004). Taming the beast: Excessive parental involvement in youth sports. Column-The New PE \& Sports Dimension. 
Gould, D., Lauer, L., Rolo, C., Jannes, C., \& Pennisi, N. (2006). Understanding the role parents play in tennis success: A national survey of junior tennis coaches. British Journal of Sports Medicine, 40(7), 632-636.

Güllich, A., \& Emrich, E. (2014). Considering long-term sustainability in the development of world class success. European Journal of Sport Science, 14(sup1), S383-S397.

Hansen, D. M., Larson, R. W., \& Dworkin, J. B. (2003). What adolescents learn in organized youth activities: A survey of self-reported developmental experiences. Journal of Research on Adolescence 13(1), 25-55.

Hendley, K. (2005). Parental involvement in youth sports.

Hill, G. M., \& Simons, J. (1989). A study of the sport specialization on high school athletics. Journal of Sport and Social Issues, 13(1), 1-13.

Hodge Jr, J. G., \& Gostin, L. O. (2001). School vaccination requirements: historical, social, and legal perspectives. $K y . L J, 90,831$.

Holt, N. L., Tamminen, K. A., Black, D. E., Sehn, Z. L., \& Wall, M. P. (2008). Parental involvement in competitive youth sport settings. Psychology of Sport and Exercise, 9(5), 663-685.

Hurst, T. R., \& Knight, J. N. (2003). Coaches' liability for athletes' injuries and deaths. Seton Hall J. Sport L., 13, 27.

Huston, J. L. (2017). Ethics of youth sports: Protecting our future. International Journal of Athletic Therapy and Training, 22(1), 33-37.

Jacobs, A. S. (2007). Family interactions within the context of organized youth sports: An examination of the sporting family identity: Southern Illinois University at Carbondale.

Jacobsson, J., Bergin, D., Timpka, T., Nyce, J. M., \& Dahlström, Ö. (2017). Injuries in youth track and field are perceived to have multiple-level causes that call for ecological (holistic-developmental) interventions: A national sporting community perceptions and experiences. Scandinavian Journal of Medicine and Science in Sports.

Jayanthi, N., Pinkham, C., Dugas, L., Patrick, B., \& LaBella, C. (2013). Sports specialization in young athletes: Evidence-based recommendations. Sports Health, 5(3), 251-257. https://doi. org/10.1177/1941738112464626

Kanters, M. A., Bocarro, J., \& Casper, J. (2008). Supported or pressured? An examination of agreement among parent's and children on parent's role in youth sports. Journal of Sport Behavior, 31(1), 64.

Kerr, Z. Y., Dalton, S. L., Roos, K. G., Djoko, A., Phelps, J., \& Dompier, T. P. (2016). Comparison of Indiana high school football injury rates by inclusion of the USA Football "Heads Up Football” Player Safety Coach. Orthopaedic Journal of Sports Medicine, 4(5), 2325967116648441.

Larson, H. J., Jarrett, C., Eckersberger, E., Smith, D. M., \& Paterson, P. (2014). Understanding vaccine hesitancy around vaccines and vaccination from a global perspective: A systematic review of published literature, 2007-2012. Vaccine, 32(19), 2150-2159.

Le Sage, L., \& De Ruyter, D. (2008). Criminal parental responsibility: Blaming parents on the basis of their duty to control versus their duty to morally educate their children. Educational Philosophy and Theory, 40(6), 789-802.

Liem, B. C., Olafsen, N. P., Harrast, M. A., \& Herring, S. A. (2016). Final comment: Return-toplay decision making: Does level of competition make a difference? $P M \& R, 8(3), \mathrm{S} 139-\mathrm{S} 143$. http://dx.doi.org/10.1016/j.pmrj.2015.09.021

Liston, K., Reacher, D., Smith, A., \& Waddington, I. (2006). Managing pain and injury in nonelite rugby union and rugby league: A case study of players at a British university. Sport in Society, 9(3), 388-402. 
Logan, K. (2015). Overuse and underutilization in youth sports: Time to seek equipoise. The Journal of Pediatrics, 166(3), 517-519. http://dx.doi.org/10.1016/j.jpeds.2014.11.024

Lowrey, K. M., Morain, S. R., \& Baugh, C. M. (2017). Do ethics demand evaluation of public health laws? Shifting scientific sands and the case of youth sport-related traumatic brain injury laws. Journal of Health Care Law \& Policy, 19(1), 99-117.

Malcom, N. L. (2006). "Shaking it off" and "Ttoughing it out" Socialization to pain and injury in girls' softball. Journal of Contemporary Ethnography, 35(5), 495-525.

McCaskey, A. S., \& Biedzynski, K. W. (1996). A guide to the legal liability of coaches for a sports participant's injuries. Seton Hall J. Sport L., 6, 7.

McEwin, C. K., \& Dickinson, T. S. (1996). Placing young adolescents at risk in interscholastic sports programs. The Clearing House, 69(4), 217-221.

McGuine, T. A., Post, E. G., Hetzel, S. J., Brooks, M. A., Trigsted, S., \& Bell, D. R. (2017). A prospective study on the effect of sport specialization on lower extremity injury rates in high school athletes. The American Journal of Sports Medicine, 0363546517710213. https://doi.org/10.1177/0363546517710213

McMahon, R. (2007). Revolution in the bleachers: How parents can take back family life in a world gone crazy over youth sports: London, UK: Penguin Publishing.

Mitten, M. J. (2002). Emerging legal issues in sports medicine: A synthesis, summary, and analysis. . John's L. Rev., 76, 5.

Moesch, K., Elbe, A. M., Hauge, M. L., \& Wikman, J. M. (2011). Late specialization: The key to success in centimeters, grams, or seconds (cgs) sports. Scandinavian Journal of Medicine and Science in Sports, 21(6).

Nixon, H. L. (1993). Accepting the risks of pain and injury in sport: Mediated cultural influences on playing hurt. Sociology of Sport Journal, 10(2), 183-196.

Ommundsen, Y., Roberts, G. C., Lemyre, P.-N., \& Miller, B. W. (2006). Parental and coach support or pressure on psychosocial outcomes of pediatric athletes in soccer. Clinical Journal of Sport Medicine: official journal of the Canadian Academy of Sport Medicine, 16(6), 522. https:// doi.org/10.1097/01.jsm.0000248845.39498.56

Roos, K. G., \& Marshall, S. W. (2014). Definition and usage of the term "overuse injury" in the US high school and collegiate sport epidemiology literature: A systematic review. Sports Medicine, 44(3), 405-421. https://doi.org/10.1007/s40279-013-0124-z

Rose, M. S., Emery, C. A., \& Meeuwisse, W. H. (2008). Sociodemographic predictors of sport injury in adolescents. Medicine and Science in Sports and Exercise, 40(3), 444-450.

Schroeder, A. N., Comstock, R. D., Collins, C. L., Everhart, J., Flanigan, D., \& Best, T. M. (2015). Epidemiology of overuse injuries among high-school athletes in the United States. The Journal of Pediatrics, 166(3), 600-606.

Shanmugam, C., \& Maffulli, N. (2008). Sports injuries in children. British Medical Bulletin, 86(1), 33-57. https://doi.org/10.1093/bmb/ldn001

Sheu, Y., Chen, L.-H., \& Hedegaard, H. (2016). Sports- and recreation-related injury episodes in the United States, 2011-2014. National Health Statistics Reports(99), 1-12.

Shields, D. L., LaVoi, N. M., Bredemeier, B. L., \& Power, F. C. (2007). Predictors of poor sportspersonship in youth sports: Personal attitudes and social influences. Journal of Sport and Exercise Psychology, 29(6), 747-762.

Sondheimer, E. (2017). High school football participation decreases in California for second consecutive year. Los Angeles Times. Retrieved from http://www.latimes.com/sports/highschool/ varsity-times/la-sp-high-school-sports-updates-high-school-football-participation-1501609327htmlstory.html 
Soprano, J. V., \& Fuchs, S. M. (2007). Common overuse injuries in the pediatric and adolescent athlete. Clinical Pediatric Emergency Medicine, 8(1), 7-14. http://dx.doi.org/10.1016/j. cpem.2007.02.009

Stracciolini, A., Casciano, R., Levey Friedman, H., Stein, C. J., Meehan, W. P., \& Micheli, L. J. (2014). Pediatric sports injuries. The American Journal of Sports Medicine, 42(4), 965-972. https://doi.org/10.1177/0363546514522393

Tofler, I. R., Knapp, P. K., \& Drell, M. J. (1999). The "Achievement by Proxy” spectrum: Recognition and clinical response to pressured and high-achieving children and adolescents. Journal of the American Academy of Child and Adolescent Psychiatry, 38(2), 213.

Vaeyens, R., Güllich, A., Warr, C. R., \& Philippaerts, R. (2009). Talent identification and promotion programmes of Olympic athletes. Journal of Sports Sciences, 27(13), 1367-1380.

Valovich McLeod, T. C., Decoster, L. C., Loud, K. J., Micheli, L. J., Parker, J. T., Sandrey, M. A., \& White, C. (2011). National Athletic Trainers' Association position statement: Prevention of pediatric overuse injuries. Journal of Athletic Training, 46(2), 206-220.

Visek, A. J., Achrati, S. M., Mannix, H., McDonnell, K., Harris, B. S., \& DiPietro, L. (2015). The fun integration theory: Toward sustaining children and adolescents sport participation. J Phys Act Health, 12(3), 424-433. https://doi.org/10.1123/ipah.2013-0180

Wade, A. (2014). Five-year-old runs 24:08 5K to shatter single-age record. Newswire. Retrieved from https://www.runnersworld.com/newswire/five-year-old-runs-2408-5k-to-shatter-singleage-record

Wiersma, L., \& Fifer, A. (2008). "The schedule has been tough but we think it's worth it": The joys, challenges, and recommendations of youth sport parents. Journal of Leisure Research, 40(4), 505-530.

Wilson, M.-F. (2010). Young athletes at risk: Preventing and managing consequences of sports concussions in young athletes and the related legal issues. Marq. Sports L. Rev., 21, 241. 